\title{
New species, possible hybrids and intergrades in Australian Nymphaea (Nymphaeaceae) with a key to all species
}

\author{
Surrey W.L. Jacobs ${ }^{1 \dagger}$ and C. Barre Hellquist ${ }^{2}$ \\ ${ }^{1}$ National Herbarium, Royal Botanic Gardens, Sydney, NSW 2000, Australia \\ ${ }^{2}$ Department of Biology, Massachusetts College of Liberal Arts, North Adams, MA 01247-4100, \\ USA \\ Author for correspondence: C.Barre.Hellquist@mcla.edu
}

\begin{abstract}
Nymphaea lukei and N. noelae, both Nymphaeaceae subgenus Confluentes, are described from the Kimberley region of Western Australia and Cape York region of Queensland respectively. The new combination and status of Nymphaea kimberleyensis is provided for Nymphaea immutabilis subsp. kimberleyensis from Western Australia. From Central Eastern Queensland Nymphaea jacobsii (subgenus Anecphya), with two subspecies, and N. vaporalis are described as new taxa. The potential hybrid origin of N. kimberleyensis and N. vaporalis is discussed, as is the presence of an intergrade complex. Another hybrid, $\mathbf{N}$. jacobsii $\times \mathbf{N}$. violacea, is described but not named. A key is provided for the native and naturalised species of Nymphaea in Australia.
\end{abstract}

\section{Introduction}

Nymphaea includes 17 native species and 4 naturalised species in Australia. We have been studying this complex genus over more than 20 years, undertaking many field trips in northern Australia to study the populations in the field. Since the Flora of Australia treatment was published (Jacobs and Porter 2007), molecular data have been helpful in understanding the complexities of breeding systems (Borsch et al. 2007; Loehne et al. 2008) in this morphologically difficult genus. Here we describe three new species in the subgenus Confluentes and one new species in subgenus Anecphya, raise one subspecies to specific rank in subgenus Anecphya, discuss the role of hybridisation in some situations, and provide a revised key to all native and naturalised species.

\footnotetext{
† Surrey Jacobs retired as Senior Principal Research Scientist from the Royal Botanic Gardens, Sydney on November 20, 2009. He died a week later on November 26, 2009. Surrey wrote most of the original version of this manuscript. We continued improving the manuscript in February 2009, with revisions following the review of the manuscript just before his death. Surrey contributed to the understanding of the Australian water-lilies and named 11 new species, including those named here, during his lifetime. As a tribute to Surrey and all his work with the water-lilies, I chose to honour him by renaming one of the new waterlilies described in this paper to Nymphaea jacobsii .
} 
Note that where multiple parts of a specimen are cited (usually a pressed specimen and flowers in alcohol) as a holotype, these are all taken from the same collection and are therefore all part of the holotype as defined in Article 8.3 of the International Code of Botanical Nomenclature (McNeill et al. 2006).

\section{Taxonomic section}

\section{Subgenus Confluentes}

Löhne et al.(2008), in their publication on evolutionary patterns in Australian Nymphaea, demonstrated a complex pattern of a genomic-based breeding system in subgenus Confluentes. There are two genomes, and $N$. violacea can be either heterogenomic or homogenomic whereas the peripheral species seem to be homogenomic for one or the other genomes. Here we describe two new species (one from the Kimberley, Western Australia and one from Cape York, Queensland) based on morphological data that are corroborated by DNA evidence provided in that study for two sets of accessions ((i) NY110, NY448; and (ii) NY413, NY419, NY420). We had recognised these two taxa as distinct some years previously but delayed their formal description as species pending a better understanding of the nuclear and plastid DNA patterns, as early results indicated a possible complex breeding system.

The type material of N. violacea is too old to permit extraction of DNA suitable for sequence analyses. The type is from 'Cape York', which covers the general area where both genomes (Löhne et al. 2008) have been recorded. However, the morphological characteristics are more than sufficient to separate the type of $N$. violacea from the Kimberley and Cape York taxa mentioned here.

Water-lilies initially identified as $N$. violacea collected in the Kimberley, Western Australia, on closer inspection appeared to be different from the typical N. violacea. This is here described as a new species.

Nymphaea lukei S.W.L.Jacobs \& Hellq. sp. nov.

$N$. violaceae similis sed petalis valde bicoloratis, margine foliis profunde sinuato, stipulis longioribus, seminibus pilis seriatim, differt.

Type: Western Australia: Dampier: March Fly Glen, c. 210 km NE Derby, Gibb River Rd, 385 m, S. Jacobs 9862, 2 May 2008. Holotype: NSW 835315. Isotypes: NSW 835318; PERTH; NASC; DNA.

Annual or perennial with a globose rhizome c. $2-2.5 \mathrm{~cm}$ diam. Leaf blade elliptic, 9.7-28 cm long, 7.2-25 cm wide; margins sinuate to strongly sinuate; stipules fused for c. $2-3 \mathrm{~cm}$, the apical lobe free, acute c. $0.5 \mathrm{~cm}$ long, rarely this lobe at right-angles to the petiole. Flowers to $30 \mathrm{~cm}$ above the water, pleasantly-scented, day-flowering. Sepals 3.5-6.5 cm long, 0.5-2.5 cm wide, green outside, outer margins deep blue especially towards the acute tip. Petals mostly 15-30, 3-6 cm long, $1.3-2 \mathrm{~cm}$ wide, lanceolate, white below, grading into deep blue or mauve above; no gap between petals and stamens; tip acute. Stamens yellow, 75-250; filaments membranous, 5-12 mm long; anthers to 4-15 mm long; appendage white, much reduced and only visible on outer stamens. Ovary usually red at the apex, with vestigial or obsolete sterile lobes; carpels 16-30. Fruit globose, c. 1.5-3 × 1.5-2.5 cm; seeds elongated, 2.1-2.5 mm long, $1.8-1.9 \mathrm{~mm}$ wide, shortly hairy with hairs to $0.03-0.06(-1) \mathrm{mm}$ long, hairs in more or less well-defined rows; epidermal cells of seed coat with minute (c. $3 \mu \mathrm{m}$ diam.) wartlike projections, often more concentrated on the lobes. 
Selection of specimens examined: Western Australia: Gardner: Dog Chain Ck, c. $200 \mathrm{~km} \mathrm{NE}$ Derby, Gibb R. Rd, Jacobs 5592 \& Wilson, 10 May 1988 (NSW280734 \& 704227); Jacobs 9864, 22 May 2008 (NSW835321; PERTH; NASC); McCarthy 267, 17 May 1988 (NSW217963). Adcock Gorge, c. 275 km NE Derby, Gibb R. Rd, Jacobs 8838 \& Hellquist 29 Jun 2002 (NSW497791 \& 513269; PERTH; NASC; B); Jacobs 9869, 23 May 2008 (NSW835319; PERTH; NASC). Dampier: March Fly Glen, Jacobs 4316, 30 May 1982 (NSW681353); Jacobs 5643 \& Wilson, 15 May 1988 (NSW389815 \& 705216); Jacobs 5660 \& Wilson, 17 May 1988 (NSW389813, 705256 \& 715256); Jacobs 8835 \& Hellquist, 28 Jun 2002 (NSW497797, 497798 \& 513270; PERTH; NASC). Brooking Gorge, Jacobs 5711 \& Wilson, 24 May 1988 (NSW681149). Fitzgerald: Lennard R., Mt Broome Rd, Jacobs 5704 \& Wilson, 21 May 1988 (NSW389811 \& 705382). Upper Lennard R., 'Mt Hart', Jacobs 4313, 4314, 29 May 1982 (NSW681350 \& 681351). Apex Ck, c. 73 km N Lennard R. crossing, Gibb R. Rd, Jacobs 8834 \& Hellquist, 28 Jun 2002 (NSW498095-97 \& 513295).

Nymphaea lukei grows in more or less perennial pools in creeks and rivers of the Western Kimberley, mainly north and west of the King Leopold Range. Flowering occurs mostly towards the end of the wet and well into the dry season. It can be distinguished from $N$. violacea by its distinctive two-coloured petals, its hairy seeds with the hairs in rows, its usually strongly sinuate leaf margins of mature leaves, and absence from floodplain billabongs. This species belongs to subgenus Confluentes and is based on material assigned formerly to $N$. violacea.

The species is named after Luke Jaden Fussell, grandson of SWLJ.

A new species from Cape York, Queensland is here described. Specimens of this species have usually been identified as N. violacea from which it differs in the less acute petals, the smaller white, rarely blue flowers and, locally, in the swollen digitate arms of the seed epidermal cells. Comparatively short swollen interdigitate arms of the epidermal cells are sometimes also recorded in N. violacea, but so far only in the Top End of the Northern Territory (Jacobs \& Porter 2007).

Nymphaea noelae S.W.L.Jacobs \& Hellq. sp. nov.

A N. elleniae petalis obtusioribus, pagina abaxiali folii viridiore, cellulis epidermalibus seminum lumene latiore non tumidove, differt.

Type: Queensland: Cook: Cape York: Jerry Lagoon, c. 24 km N of Coen- Ranger Station Rd on Langi Lagoon Rd [Mungkan-Kanju National Park (Rokeby National Park)], alt. 73 m, S. Jacobs 9668 \& C.B. Hellquist, 17 Jun 2007. Holotype: NSW 835348 (sheet), 833758 \& 833759 (both spirit). Isotypes: NASC; BRI.

Annual or perennial with a globose rhizome c. $2 \mathrm{~cm}$ diam. Blade elliptic to sub-orbicular, $13.5-23 \mathrm{~cm}$ long, $10.5-22 \mathrm{~cm}$ wide, undersurface green in centre, often purple towards margin; margins slightly or barely sinuate; stipules fused for $1(-6) \mathrm{cm}$, the apical lobe free, acute, to c. $1 \mathrm{~cm}$ long. Flowers to $30 \mathrm{~cm}$ above the water, faintly-scented, dayflowering. Sepals 4, 7.5-8.0 cm long, 2.3-2.6 cm wide green outside; tip acute. Petals 12-20, 4.5-6.0 cm long, 1.2-2.0 cm wide, lanceolate, white or sometimes with some faint blue, grading into the stamens, no gap between petals and stamens; tip broad to acute. Stamens yellow, 100-200; filaments membranous, 8-18 mm long on larger stamens; anthers 2-12 mm long on larger stamens; appendage yellow to white, much reduced and only visible on outer stamens. Ovary sometimes red at the apex, with vestigial or obsolete sterile lobes; carpels $14-16$. Fruit globose, $4-5 \mathrm{~cm}$ long, $3 \mathrm{~cm}$ diam.; seeds elongated, 1.2-2 mm long, 0.8-1.4 mm wide, glabrous; epidermal cells with the lumen wider than the interdigitate arms but not swollen; interdigitate arms swollen. 
Selection of specimens examined: Queensland: Cook: Cape York: Bobs [?Jerry] Lagoon, c. 24 km N of Rokeby Ranger Station Rd, Hellquist 16761, Aug 2002 (NASC; NSW835320; BRI); Twin Lagoon, c. $25 \mathrm{~km} \mathrm{~N}$ of Coen-Ranger Station Rd [Mungken-Kanju (Rokeby) National Park] on Langi Lagoon Rd, Jacobs 9667 \& Hellquist, 17 Jun 2007 (NSW833760, 833761 \& 835347; NASC; BRI); 22 km N Weipa turn-off, Bamaga Rd, Jacobs $9665 \&$ Hellquist, 16 Jun 2007 (NSW833762 \& 835346; NASC; BRI; MEL); c. 22 km W of Bamaga Rd on 'Batavia Downs' Rd, Jacobs 9662 \& Hellquist, 16 Jun 2007 (NSW833756; 833757 \& 835349; NASC; BRI).

Nymphaea noelae grows in near-perennial billabongs and lagoons whereas N. elleniae grows in rivers and streams, often on sandy substrates. This species can be distinguished from $N$. elleniae by the less acute petals, the epidermal cells of the seeds with a broader non-swollen lumen, and comparatively shorter (swollen) interdigitate arms.

The species is named for Noel Elizabeth Hellquist, granddaughter of $\mathrm{CBH}$.

Northeast of Charters Towers, Queensland is the old railway town of Mingala. Between the rail line and the road is an old dam built to supply water for steam engines, now part of the town water supply. This dam is more or less covered with a blue-flowered Nymphaea. This Nymphaea is intermediate in some respects between subgenus Confluentes and subgenus Anecphya, mainly in the presence of the subg. Anecphya character of an indistinct gap between the petals and the stamens; indistinct only because there are a few scattered membranous filaments across the gap. While it appears this taxon is of possible hybrid origin, it does not appear to be a simple F1 or F2 as the plants have a preponderance of characters of subgenus Confluentes (sinuate leaf margins, scented flowers, small glabrous seeds). There is a high proportion of aborted seed but substantial seed is still produced and it germinates readily (Hellquist, unpublished). No other species are present in the dam or visible nearby and, from the map, it does not appear there are suitable habitats in the immediate vicinity, though there are some potential habitats within 5-6 km (Pandanus Ck, Station Ck). Due to the seed size we regard this as a population in the subgenus Confluentes.

Because this appears to be a stable self-maintaining population of potential hybrid origin, but without either parent growing close by, we here provide a name (N. vaporalis) and description for this taxon above.

Nymphaea vaporalis S.W.L. Jacobs \& Hellq. sp. nov.

N. violaceae affinis, sed seminibus majoribus, petalis staminibusque zona manifesta separatis, differt.

Type: Queensland: North Kennedy: Old railway dam, c. 1 km W of Mingela, 1952.664'S 146 37.695'E 287 m, S. Jacobs 9637 \& C.B. Hellquist, 10 Jun 2007. Holotype: NSW 835329 (sheet), NSW 833775 (spirit). Isotypes: NASC; BRI.

Annual or perennial with a globose rhizome. Blade elliptic to sub-orbicular, to c. $33 \mathrm{~cm}$ long, to c. $28 \mathrm{~cm}$ wide; margins almost entire to sinuate; stipules $1.5-3.7 \mathrm{~cm}$ long, the apical lobe free, acute, c. $1-3 \mathrm{~mm}$ long, this lobe from erect, $45^{\circ}, 75^{\circ}$ or at right angles to the petiole. Flowers to $30 \mathrm{~cm}$ above the water, day-flowering, with a faint cinnamonlike odour. Sepals to $12 \mathrm{~cm}$ long and $3.5 \mathrm{~cm}$ wide, green outside, outer margins blue especially towards the tip; tip acute. Petals mostly to (10-)22-25 cm long, $1.8-2.5 \mathrm{~cm}$ wide, lanceolate, white below, grading into blue above; tip acute to broad acute; gap between petals and stamens interspersed with scattered broad membranous filaments. Stamens yellow, to c. 200; filaments membranous, to c. $2.3 \mathrm{~cm}$ long on larger stamens; anthers to c. $0.8 \mathrm{~cm}$ long; appendage white, much reduced and only visible on outer 
stamens. Ovary with vestigial sterile lobes; carpels c. 18 . Fruit globose, c. $4 \times 3 \mathrm{~cm}$; seeds elongated, c. 2-2.6 $\mathrm{mm}$ long, $1.5 \mathrm{~mm}$ wide, glabrous; high proportion of aborted seed; fully formed seed fertile.

Specimen examined: Queensland: North Kennedy: c. $1 \mathrm{~km}$ W of Mingela, Jacobs 9638 \& Hellquist, 10 Jun 2007 (NSW833776 \& 835328; NASC; BRI).

The species is named vaporalis- 'of steam, smoke' - for the old steam engine water supply near Mingala where this species grows, thus far the only known locality for this taxon of possible hybrid origin.

\section{Subgenus Anecphya}

Löhne et al. (2008) concluded that Nymphaea immutabilis subsp. kimberleyensis was likely of hybrid origin. One parent was proposed as $N$. violacea and the other an unknown species of subgenus Anecphya. While the second parent was not clear, they suggested it was more likely to be a species other than N. immutabilis. However Löhne et al. (2008) also suggested a more careful examination, including additional markers and detailed morphological analysis, would be necessary to better determine the history of this species. No other species grows with $N$. immutabilis subsp. kimberleyensi at the Fitzroy Crossing, Western Australia, site or in the immediate vicinity. Whilst $N$. violacea has been recorded from that general area of the Kimberley, there are no records of any species of subgenus Anecphya, though searching has not been exhaustive. The closest known record to date is for N. macrosperma (or aff. from near Wyndham, Western Australia, approximately $425 \mathrm{~km}$ to the northwest.). With only limited opportunities to search, we have been unable to find mature seed in the only known population of Nymphaea immutabilis subsp. kimberleyensis. We have found immature seed and the remains of eaten-out fruit. The population is self-maintaining and there is no suggestion it is of recent origin. As it is misplaced as a subspecies of N. immutabilis, and because of its possible hybrid origin, we here raise it to specific rank.

Nymphaea kimberleyensis (S.W.L.Jacobs) S.W.L.Jacobs \& Hellq. comb. et stat nov.

Basionym: Nymphaea immutabilis subsp. kimberleyensis S.W.L.Jacobs (1992: 638).

Type: Western Australia: Dampier: Kimberley region, S.W.L. Jacobs 5706 \& P.G. Wilson, 23 May 1988. Holotype: NSW 280702 (sheet), NSW 704374 (spirit). Isotype: PERTH.

An area centred on Charters Towers (Central Eastern Queensland) shows high variability in native Nymphaea populations. It is an area where suspected hybrids between subgenera are comparatively common, and where several populations seem to represent intergrades between species in the subgenera Anecphya and/or Confluentes (personal observations). Unfortunately, DNA studies are yet to help in interpreting the situation. This is our first attempt to describe some of that variability. Details of the taxa found in several localities are discussed below.

\section{Lake Powlathanga}

Lake Powlathanga west of Charters Towers is a large (c. 320 ha) ephemeral lake that is marked on maps as having a more or less perennial deeper section. It is part of the Balfe Creek drainage/flood system. In appropriate seasons the whole lake produces a spectacular display of Nymphaea.

The Nymphaea in the lake can be best treated as three taxa. When the lake is completely 
full there is a zone of $N$. violacea in the shallowest margins. The huge mass and number of plants that produce the spectacular display over the bulk of the lake is of a newly described species Nymphaea jacobsii, subgenus Anecphya. In a narrow zone between the two species there are apparent hybrid plants growing in slightly deeper water than N. violacea (subgenus Confluentes). This hybrid appears to be an F1 or F2.

Various factors, possibly rainfall and depth of lake, seem to influence whether none, one, two or three of these taxa are present on the lake at any one time. During the 1997 visit to the lake only the hybrid was observed. The N. violacea has often all but disappeared by the time vehicle access is possible. In some years there are only scattered hybrid plants growing. This is why it has taken some time to piece the story together. Below we provide a description but no formal name for the hybrid as we do not believe it is stable and self-maintaining, though we do believe it is a regular component of the Nymphaea flora of the lake. The hybrid is intermediate between the two proposed parents, and produces a minute amount of fully-formed viable seed (Hellquist unpublished).

\section{'Toomba' Station}

The populations on 'Toomba' Station, NW of Charters Towers, vary mainly in stipule characters, a character that is reasonably stable and useful elsewhere. Stipule size and shape varies from the short stipules with lateral lobes characteristic of $N$. gigantea to some of the longest stipules recorded for subgenus Anecphya $(20 \mathrm{~cm})$. The seed characters approach those of $N$. jacobsii (though, again, with some variability), while the flower characters are reminiscent of $N$. immutabilis. Because of the mixing and variability of characters (even within a location), the best way to deal with this complex of intergrades is not immediately clear to us. We have chosen to place all of the forms, and indeed some other forms growing nearby that we have refrained from listing for conservation reasons into a subspecies of $N$. jacobsii ( $N$. jacobsii subsp. toomba).

\section{Nymphaea jacobsii Hellq. sp. nov.}

N. giganteae affinis, sed seminibus majoribus (ad $7 \mathrm{~mm}$ longis), pilis seminum seriebus anastomosantibus, differt.

Type: Queensland: North Kennedy: 'Powlathanga', 20¹2.016'S 14558.868'E 323 m, S. Jacobs 9647 \& C.B. Hellquist, 12 Jun 2007. Holotype: NSW 835333 (sheet), NSW 833773 \& 833774 (both spirit). Isotypes: NASC; BRI.

Annual or perennial with a globose to elongate rhizome. Blade broad-elliptic, to $40 \mathrm{~cm}$ long, to $35 \mathrm{~cm}$ wide; margins finely dentate with teeth 1-6 $\mathrm{mm}$ long; stipules $1-7(-20) \mathrm{cm}$ long, $1.8-6.0 \mathrm{~cm}$ wide, the apical lobe free, acute $<1-7(-10) \mathrm{mm}$ long, this lobe erect to at right angles to the petiole. Flowers erect to $30 \mathrm{~cm}$ above the water, day-flowering, not scented. Sepals $4.2-13 \mathrm{~cm}$ long, $5.5 \mathrm{~cm}$ wide, green outside, outer margins blue especially towards the tip, sometimes with dark flecks; tip acute to broad acute. Petals $12-24,1-11.5 \mathrm{~cm}$ long, to $2.5-5.5 \mathrm{~cm}$ wide, lanceolate, white below, grading into deep blue; obvious gap between petals and stamens; tip acute to broadly acute. Stamens yellow, c. 150-300; filaments membranous, to $<1-3 \mathrm{~mm}$ long on larger stamens; anthers $0.7-1.8 \mathrm{~mm}$ long; appendage white, much reduced and only visible on outer stamens. Ovary with vestigial or obsolete sterile lobes; carpels 12-25. Fruit globose, 2.3-9 cm diam.; seeds large, ovoid, 2.6-7 $\mathrm{mm}$ long, 2-3.5 $\mathrm{mm}$ wide, with hairs 0.1-0.13 $\mathrm{mm}$ long, the hairs in well-defined anastomosing rows. 
This species is named for Surrey W.L. Jacobs, former botanist at the Royal Botanic Gardens, Sydney and Australian water-lily expert.

The two subspecies can be identified as follows:

1 Flowers generally larger with sepals $9.5-13 \mathrm{~cm}$ long, petals $6.5-11.5 \mathrm{~cm}$ long; fruit to $8-9 \mathrm{~cm}$ diam.; seeds 4.4-7 mm long . subsp. jacobsii

$1^{\star}$ Flowers generally smaller with sepals to $4.2-8.5 \mathrm{~cm}$ long, petals to $5-8.5 \mathrm{~cm}$ long, fruit (2-5-)4-7 cm diam.; seeds 2.6-5(-6) mm long subsp. toomba

\section{N. jacobsii subspecies jacobsii}

Annual or perennial with a globose rhizome. Blade broad-elliptic, 19-40 cm long, 17$32 \mathrm{~cm}$ wide; margins finely dentate with teeth $1-4 \mathrm{~mm}$ long; stipules c. $2-3.5 \mathrm{~cm}$, the apical lobe free, acute c. $1-6 \mathrm{~mm}$ long, this lobe erect to at right angles to the petiole. Sepals 9.5-13 cm long, 3.1-5.5 cm wide, green outside, outer margins blue especially towards the tip, sometimes with dark flecks; tip acute to broad acute. Petals mostly 14-24, 6-11.5 cm long, 3.2-5.5 cm wide, lanceolate, white below, grading into deep blue; obvious gap between petals and stamens; tip acute. Stamens yellow, 150-300; filaments membranous, $10-30 \mathrm{~mm}$ long on larger stamens; anthers $0.8-1.4 \mathrm{~mm}$ long. Ovary with vestigial or obsolete sterile lobes; carpels 16-20. Fruit globose, to c. 8-9 cm diam.; seeds large, ovoid, $4-7 \mathrm{~mm}$ long, $2.4-2.8 \mathrm{~mm}$ wide; with hairs to $0.1-0.13 \mathrm{~mm}$ long, the hairs in well-defined anastomosing rows.

Specimen examined: Queensland: Lake Powlathanga, W of Charters Towers, Jacobs 9654 \& Hellquist, 12 Jun 2007 (NSW833770 \& 835337; NASC; BRI).

\section{N. jacobsii subspecies toomba Hellq. subsp. nov.}

Subspeciei typicae similis, sed floribus minoribus (sepalis ad $8.5 \mathrm{~cm}$ longis, petalis ad $8.5 \mathrm{~cm}$ longis), fructibus ad $7 \mathrm{~cm}$ diametro, differt.

Type: Queensland: North Kennedy: 'Toomba', Toomba Creek, Canal Paddock, W of Charters Towers, 393 m, S. Jacobs 9643 \& C.B. Hellquist, 11 Jun 2007. Holotype: NSW 835316 (plant on sheet), NSW 833763 (rhizomes), NSW 833753 \& 833754 (both spirit). Isotypes: BRI; NASC; B; MEL.

Annual or perennial with a globose to elongate rhizome to c. $25 \mathrm{~cm}$ long. Blade broad-elliptic to suborbicular, $29-75 \mathrm{~cm}$ long, $27-35 \mathrm{~cm}$ wide; margins finely dentate with teeth 1-6 mm long; stipules $1-7(-20) \mathrm{cm}$ long, the apical lobe free, acute, $<1-10 \mathrm{~mm}$ long, this lobe erect to at right-angles to the petiole. Sepals $4.2-8.5 \mathrm{~cm}$ long, $4.2-6.0 \mathrm{~cm}$ wide, green outside, outer margins blue especially towards the tip, sometimes with small dark flecks; tip obtuse to broad acute. Petals mostly 12-20, 5-8.5 cm long, 2.5-4 cm wide, lanceolate, white below, grading into deep blue; obvious gap between petals and stamens; tip acute. Stamens yellow, c. 150-300; filaments membranous, $<10-22 \mathrm{~mm}$ long on larger stamens; anthers to $7-16 \mathrm{~mm}$ long. Ovary with vestigial or obsolete sterile lobes; carpels 12-25. Fruit globose, (2.5-)4-7 cm diam.; seeds large, ovoid, to $2.6-5(-6) \mathrm{mm}$ long, $2-3 \mathrm{~mm}$ wide, with hairs to c. $0.1 \mathrm{~mm}$ long, the hairs in well-defined anastomosing rows.

Selection of specimens examined: Queensland: North Kennedy: Oakey Lake 'Toomba', Jacobs 9641 \& Hellquist, 11 Jun 2007 (NSW833694, 833695, 835322 \& 835323; BRI; NASC); Toomba Spring Creek 'Toomba', Jacobs 9646 \& Hellquist, 11 Jun 2007 (NSW833751, 833752 \& 835324; NASC). 
The subspecies is named after Ernest and Robyn Bassingthwaighte's property, 'Toomba', in appreciation of their friendship and assistance provided over the years.

\section{Nymphaea jacobsii $\times N$. violacea}

Annual or perennial with a globose rhizome. Blade elliptic to suborbicular, to $37 \mathrm{~cm}$ long, to $31 \mathrm{~cm}$ wide; margins sinuate with small teeth to c. $1 \mathrm{~mm}$ long erratically developed, lacking spines; stipules short, the apical lobe free, c. 30-50\% the length, acute, erect. Flowers to $30 \mathrm{~cm}$ above the water, day-flowering. Sepals to $10 \mathrm{~cm}$ long, $4.5 \mathrm{~cm}$ wide, green outside, outer margins blue especially towards the tip with some streaking; tip acute to obtuse. Petals mostly 18-22, to $11 \mathrm{~cm}$ long, $5.5 \mathrm{~cm}$ wide, spathulate, white below, grading into light blue; no gap between petals and stamens; tip acute to obtuse. Stamens yellow, c. 400-500; filaments membranous, to c. $3 \mathrm{~cm}$ long on larger stamens; anthers to c. $1.5 \mathrm{~cm}$ long; appendage white, much reduced and only visible on outer stamens. Ovary with vestigial or obsolete sterile lobes; carpels 18-22. Fruit globose, c. 2-5 cm diam.; seeds elongated, c. $2 \mathrm{~mm}$ long, $1.5 \mathrm{~mm}$ wide, shortly hairy with hairs to c. $3 \mu \mathrm{m}$ long, the hairs in more or less irregular rows; seed set very low.

Selection of specimens examined: Queensland: North Kennedy: Lake Powlathanga, W of Charters Towers, Jacobs 9652, $9653 \&$ Hellquist, 12 Jun 2007 (NSW835330 \& 835332; NASC).

Specimens from north of the Great Basalt Wall that we originally considered as potentially belonging to this complex we are now happy identifying as N. macrosperma and N. carpentariae. Clearly this is a zone where many species of subgenus Anecphya grow, and the presence of intergrades is not surprising.

\section{Key to native and naturalised species of Nymphaea in Australia}

1 Petals yellow; horizontal stolons and vertical rhizomes both present. ........ ${ }^{\star} N$. mexicana ${ }^{1}$

$1^{\star}$ Petals white, blue, mauve or pink; stolons absent; rhizomes either horizontal, or vertical and more or less tuberous.

2 Rhizomes horizontal or suberect, elongated and vigorous; flowers more or less floating on the water surface. ${ }^{\star} N$. alba, ${ }^{\star} N$. odorata and hybrids

$2 *$ Rhizomes tuberous, erect; flowers emerging distinctly above the water surface. ............... 3

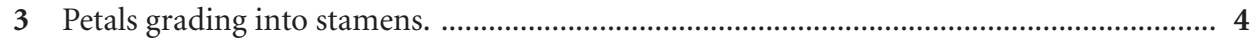

$3^{*}$ Distinct gap present between petals and sepals. ...................................................... 12

4 Filaments tough and thickened, always flattened; leaf blade margin dentate the undersurface usually pubescent; flowers opening in the evening and remaining open to mid-day; widespread from northern Queensland and Northern Territory to SE Asia and India.

N. pubescens

$4^{\star}$ Filaments membranous and either cylindrical, or all flattened, or only some outer filaments flattened; leaf blade margin sinuate, the undersurface always glabrous; flowers opening during the morning and closing during the later afternoon.

${ }^{1}$ The plant introduced in Australia may be a hybrid involving this species, rather than pure N. mexicana, as in other places where this taxon is said to be introduced 
5 Apical anther appendage present, $0.5-10 \mathrm{~mm}$ long; anthers to $25.5 \mathrm{~mm}$ long: stamens the same colour as the petals toward apex; coastal from central Queensland south to central New South Wales.

N. caerulea ${ }^{2}$

$5^{\star}$ Apical anther appendage absent or $<0.5 \mathrm{~mm}$ long, anthers to $13 \mathrm{~mm}$ long; stamens yellow or cream-colored; widespread from northern New South Wales north and throughout the Australian tropics. 6

6 Flowers blue, mauve, pink, or blue-mauve-tipped, white below. ………............................ 7

$6^{*}$ Flowers white or white with a very faint blue tinge. ........................................................... 9

7 Seeds hairy, 2.1-2.5 mm long; petals blue or mauve-tipped, white toward base; restricted to W. Kimberley, Western Australia. N. lukei

7* Seeds glabrous, 1.25-2.2 mm long; petals blue, mauve, or pink; widespread throughout tropical Australia. N. violacea

8 Ovary tips yellow; common throughout the Australian tropics. 9

$\mathbf{8}^{\star}$ Ovary tips red or reddish-maroon; restricted to Normanton area and central Cape York, Queensland.

9 Stamens 50-100; filament length 3-9 mm; sepal width 6-8 mm; plants of far northern regions of Northern Territory and Western Australia; plants occur around margins of water-bodies during wet season.

N. hastifolia

9* Stamens 100-300; filament length 4-25 mm; sepal width 6-28 mm; found throughout Australian tropics; plants mostly of permanent waters.

10 Plants usually retaining submerged juvenile leaves; flowers with slight fragrance; lower leaf surface deep purple-red; plants in vicinity of Jardine River, northern Cape York, Queensland. N. elleniae

$10^{*}$ Plants lacking juvenile submerged leaves; flowers strongly fragrant; lower leaf surface green to green and light red; plants widely distributed throughout tropical Australia

N. violacea

11 Stamens cream-colored; tip of ovary bright red; petals white; sepal width $0.4-1.9 \mathrm{~cm}$; stipules to $1 \mathrm{~cm}$ long; seeds with longitudinal ridges and these often with proliferations; plants restricted to area around Normanton, Queensland; in shallow waters during wet season. N. alexii

$11^{\star}$ Stamens yellow; tip of ovary reddish-maroon; petals white (rarely faint blue); sepal width 2.3-2.6 cm; stipules 1-6 cm long; seeds lacking longitudinal ridges or proliferations; plants restricted to central Cape York, north of Coen, Queensland; in mainly permanent waters.

\section{N. noelae}

12 Filaments coarse, flattened; leaf blade margin sinuate; mature seed 0-1.5 mm long; petals usually 6-10, stamens 15-25; widespread from Cape York, Queensland, and the Top End, Northern Territory, to SE Asia and India.

N. nouchali

$12 \star$ Filaments membraneous, slightly flattened to cylindrical; leaf blade margin dentate, rarely entire to sinuate; mature seed greater than $2.5 \mathrm{~mm}$ long; petals usually more than 10 ; stamens 50-400.

${ }^{2}$ The introduced plant in eastern Australia is not typical of N. caerulea, described from Egypt, but better fits what has traditionally been treated as N. capensis. Further work on the interpretation of types is required. 
13 Seeds glabrous, sparsely produced, $2-2.6 \mathrm{~mm}$ long, to $1.5 \mathrm{~mm}$ wide, elongate; leaf margin almost entire to sinuate; plants of north-central Queensland near Charters Towers.

\section{N. vaporalis}

$13 *$ Seeds commonly produced, with hairs, $1.2-6.4 \mathrm{~mm}$ long, 0.3-6 mm wide, ovoid, ellipsoid, globose, or subglobose; leaf margin dentate.

14 Upper leaf surface with distinct dimples; sepals and outer petals blue, mauve, or pink coloured, inner petals white.

14* Upper leaf surface not dimpled; petals uniformly coloured or only lighter in the centre. 16

15 Seeds oblong (to ovate); leaf margin teeth $<1-2 \mathrm{~mm}$; flowers with petals of various colours; sepals and first row of petals blue or white transitioning to pink, dark pink, and eventually red; uncommon, mainly in and near Lakefield National Park, Cape York, Queensland.

N. atrans

$15^{\star}$ Seeds ovate (-to oblong); leaf margin teeth $1-4.5 \mathrm{~mm}$; flowers with sepals usually green and/or blue and outer whorl of petals blue, mauve, or pink, occasionally with dark pink bases, usually stable colour; common in NE Queensland.

N. immutabilis

16 Sepals 9-18.5 cm long; petals 9.5-14.5 cm long; fruit not developing; plants of southcentral Kimberley, Western Australia. N. kimberleyensis

16* Sepals 2.5-8.5 cm long; petals 1.5-9 cm long; fruit developing; plants widespread. 17

17 Seeds 1-3 mm long, mostly globose to slightly subglobose, petals mostly white, also blue, pink, and mauve.

$17^{\star}$ Seeds 2.6-6.4 mm long, ovoid to subglobose; petals mostly blue, rarely white, or pink. .. 19

18 Teeth on leaf margins 2-4 mm long; stipules 1-3 cm long; seeds globose with \pm continuous rows of short hairs; petals not fading with age; plants predominantly of Lake Eyre drainage.

N. georginae

$1 \mathbf{1 8}^{\star}$ Teeth on leaf margins to $1.5 \mathrm{~mm}$ long; stipules $1-8 \mathrm{~cm}$ long; seeds globose or subglobose with often interrupted rows of short hairs; non-white petals fading with age; plants mainly of the Gulf of Carpentaria drainage.

N. carpentariae

19 Sepals heavily-streaked, rarely flecked; seeds subglobose; flowers usually small, erect, occasionally floating, diameter 4-9 mm, with sepals $2.3-4.5(-6) \mathrm{cm}$ long. Northern Queensland, Northern Territory and adjacent parts of New Guinea.

N. macrosperma

$1{ }^{*}$ Sepals un-flecked to flecked; seeds ovoid; flowers larger, erect, diameter 8-30 cm, sepals mostly $4-10 \mathrm{~cm}$ long.

20 Petal tips blunt: fruit $3-5 \mathrm{~cm}$ wide at widest point; stipules $1-1.5 \mathrm{~cm}$; petals fading with age; plants of eastern Queensland, south to NE. New South Wales.

N. gigantea

$20^{\star}$ Petal tips acute to broadly acute; fruit $(2.5-) 4-9 \mathrm{~cm}$ diam. at widest point; stipules $1-7(-20) \mathrm{cm}$; petals not fading with age; plants of north-central Queensland near Charters Towers. 


\section{Acknowledgments}

We thank Karen Wilson (NSW) for the Latin diagnoses, Liz Norris for SEM photographs of the seeds, Ernest and Robyn Bassingthwaighte ('Toomba') for continued friendship and help in the field, Donald Les, University of Connecticut, Storrs, Connecticut, USA, and Michael Moody, Department of Environment and Conservation University of Western Australia, Perth, Western Australia for their suggestions and critical review of the manuscript.

\section{References}

Borsch T, Khidir WH, Wiersema JH, Löhne, C, Barthlott, W. \& Wilde, V. (2007) Phylogeny of Nymphaea (Nymphaeaceae): Evidence from substitutions and microstructural changes in the chloroplast trnT-trnF region. International Journal of Plant Science 168: 639-671.

Jacobs SWL (1992) New species, lectotypes and synonyms of Australasian Nymphaea (Nymphaeaceae). Telopea 4: 635-641.

Jacobs SWL and Porter CL (2007) Nymphaeaceae. Pp. 259-275 in Wilson AJG (ed.) Flora of Australia, vol. 2. (Australian Government Publishing Service: Canberra)

Löhne C, Borsch T, Jacobs SWL, Hellquist CB \& Wiersma J (2008) Nuclear and plastid DNA sequences reveal complex evolutionary patterns in Australian water-lilies (Nymphaea subgenus Anecphya, Nymphaeaceae). Australian Systematic Botany 21: 229-250.

McNeill J, Barrie JFR, Burdet HM, Demoulin V, Hawksworth DL, Marhold K, Nicolson DH, Prado J, Silva PC, Skog JE, Wiersema JH (2006) International Code of Botanical Nomenclature (Vienna Code). (ARG Gantner Verlag KG: Ruggell)

Manuscript received 25 February 2009, accepted 12 May 2010 